\title{
Evaluating the Development of Competences of Students in the Master-Level Course in Socioemotional Learning for Personal and Professional Development (MAESE)
}

\author{
Ana Rodriguez Martínez ${ }^{1, *}$, Alejandra Cortés Pascual ${ }^{1}$, Cesar Rodriguez-Ledo $^{2}$ \& Francisco \\ Royo $^{2}$ \\ ${ }^{1}$ Faculty of Education, University of Zaragoza, Spain \\ ${ }^{2}$ Department of Education, Culture and Sports, Government of Aragon, Spain
}

Received: May 1, 2020 Accepted: May 13, $2020 \quad$ Published: May 22, 2020

doi:10.5296/ije.v12i2.16822 URL: https://doi.org/10.5296/ije.v12i2.16822

\begin{abstract}
The purpose of this work is to evaluate the impact that the Master-level course in Socioemotional Learning for Personal and Social Development (hereinafter MAESE) has had on socioemotional skills, positive psychology (dispositional optimism and satisfaction with life), the level of communicative and teamwork skills developed through coaching, and the capacity for entrepreneurship and innovation in the students of four consecutive graduating classes. This Master-level course has been taught at the University of Zaragoza in a blended-instruction form since 2014 and is currently in its sixth year. The methodology used here is eminently quantitative through an ex post facto descriptive study, although in the coaching and entrepreneurship block, qualitative information is also collected through open-ended questions. The results show that after completing the MAESE, there are few significant improvements in socioemotional skills (MSCEIT). On the other hand, there are significant improvements in the participants' dispositional optimism (Life Orientation Test), satisfaction with life (SWLS), skill development through coaching, and ability to undertake projects and to innovate (PTWS). We conclude by reinforcing the importance of and responsibility to evaluate the impact that university training has on its students, especially for degrees covering emotion-related content.
\end{abstract}

Keywords: socioemotional learning, positive psychology, coaching, entrepreneurship, innovation 


\section{Introduction}

Our society needs people to be equipped with a wide variety of skills, especially those that are related to the management of emotions, attitude towards life, flexibility, the ability to resolve conflicts, and the ability to adapt to the unexpected (Repetto \& Pérez-González, 2007). This need is not only about knowing, or knowing how to do, but also about wanting to do and knowing how to be. Despite the importance that society and businesses give to these and other transversal competences, educational institutions usually lack training in them (Cabello, Ruiz-Aranda, \& Fernández-Berrocal, 2009). Education must have a fundamental commitment to this societal demand, and the best way to develop these skills is through the evaluation of training experiences that aim to develop these emotional competences (Herzberg, Glaesmer, \& Hoyer, 2006).

One such project arose from a group of teachers concerned about the need to train future professionals in emotional life skills. As a result of this concern, and after much effort, the first Master-level course in socioemotional learning for personal and professional development (MAESE) began in 2014, now in its sixth year in 2019-2020. This project stems from the idea of training students not only in technical knowledge related to the development of socioemotional skills in the professional world but also in developing certain personal skills, in an attempt to improve their socioemotional intelligence (SEI), to promote optimistic attitudes from positive psychology approaches, to develop communicative and teamwork skills through coaching, and to promote the entrepreneurial and innovative skills of students.

The course has four pillars: 1) socioemotional learning (SEI), 2) positive psychology, 3) communicative and team coaching, and 4) entrepreneurship and innovation. These are held to be the backbone of the MAESE and therefore have defined the main modules of this Master course. Each of these groups of competences has been explored through active and practical training techniques, based on theoretical models and existing literature.

The first of the pillars, SEI, starts from the understanding of emotion as an internal construct that energizes our behavior so that we respond to our environment by coming nearer or moving away, depending on whether the emotions have a positive or negative hedonic tone (Ekman \& Davidson, 1994). Intelligence is understood as the ability to adapt to the environment based on a series of fluid and crystallized abilities and potentials. Therefore, we work to enhance our students' SEI, defined as their ability to perceive, understand, regulate, and express such emotional events in an adaptive way (Rodríguez-Ledo, Orejudo Hernández, Celma Pastor, \& Cardoso Moreno, 2018). SEI is a framework encompassing how feelings are perceived, regulated, and expressed with some amount of skill.

The second of the pillars of training in MAESE has focused on the development of positive psychology competences, specifically human strengths, positive emotions, and institutions that promote both areas of well-being and personal and professional development. One of the strengths that has been especially emphasized is optimism. Two different theoretical models address this construct: dispositional optimism (Carver \& Scheier, 2002, 2005; Scheier \& Carver, 1985, 1992) and optimistic attributional style (Gillham, Shatté, Reivich, \& Seligman, 2002; Peterson \& Steen, 2005). In the first, optimism refers to the expectations that people 
have about reaching their goals. These expectations can range from the optimistic pole, perceiving the goals as achievable, to the pessimistic pole, perceiving them as impossible or very difficult to achieve. Within self-regulation models, expectations are considered to influence the behaviors and emotions generated (Caver \& Scheier, 2002). The second model has its origin in the reformulated theory of learned helplessness (Abramson, Seligman, \& Teasdale, 1978; Gillham et al., 2002; Seligman \& Peterson, 1986). According to this model, both optimism and pessimism are related to attributions regarding positive and negative events that occurred in the past. The fundamental difference between the two models is that, in the first, optimistic and pessimistic beliefs refer to future expectations, while in the second, they refer to attributions of past events. They have a certain relationship that resides in the perception of control, since it is present both in past events and in future expectations (Gillham et al., 2002). On the other hand, satisfaction with life refers to a process of cognitive judgment that is intimately linked with the competences developed in positive psychology (positive reinterpretation of past events, openness, etc.). We understand it as a person's overall evaluation of their quality of life according to their previously chosen criteria. It includes achieving life, personal, and professional goals and a feeling of well-being (Shin \& Johnson, 1978). In addition, there is a strong relationship between mindfulness and SEI, and socioemotional competences are improved when they are enhanced together with this ability to be "fully in the moment" (Rodríguez-Ledo, Orejudo, Cardoso, Balaguer, \& Zarza-Alzugaray, 2018).

The third of the pillars is the development of communication and team coaching competences. The term "coaching" has been defined as the process of encouraging change and/or improvement, performed by a coach, to help the coached person give their best and to achieve the best outcome possible according to their abilities (Cortés, 2019; Cortés \& Vázquez, 2018). In other words, it is a synchronous process whereby the coach brings out the best in a person or a group through methods that are fundamentally based on effective and affective communication from different perspectives (neurolinguistic programming, emotional intelligence, mindfulness, positive psychology, neuroscience, etc.). In the MAESE, coaching is used to enhance the communication and teamwork competences of the participants, although it has also sought the development of other personal and professional competences, such as leadership, intrapersonal and interpersonal well-being, and achievement of goals, all of these being closely linked to self-direction and the effectiveness of the person and the organization (Bozer \& Jones, 2018; Cortés, 2019; Díaz, Cortés, \& Serra, 2019). In this way, the aim is to achieve self-coaching in a personalized way. Its reference to the term coachability is interesting. This is a multidimensional construct that reflects the combination of personality traits, such as agreeability or openness to experience, and motivational components, such as achievement motivation, that are necessary for good functioning and performance (Theeboom, Beersma, \& van Vianen, 2013, p. 13).

Finally, the fourth backbone of MAESE is based on the development of competences and attitudes related to entrepreneurship and innovation. We understand competence as an integrated set of knowledge, aptitudes, attitudes, and values that facilitate the effective and efficient development of a task or activity (individual or group) (Rodríguez, Cano, \& Cortes, 
2018). Therefore, we do not think of entrepreneurship as the mere ability to start a business. We focus on a broader life view, under which the person sets goals, takes action, and learns from difficulties and successes in an innovative way.

In our work, the above concepts are focused toward undertaking the most important project of our life, our own life project. From this perspective, entrepreneurship represents a proactive attitude, a risk, a learning process, and a path of uncertainties, frustrations, emotions, and learning. We agree with Bueno (2012) when he alludes to entrepreneurship and innovation as catalysts during a crisis or unexpected impact, a crisis such as the one we are currently experiencing with COVID-19, or however it may present itself in an uncertain future. Entrepreneurial competence and innovation generate possibilities that help build a society that converts ideas into value (Reyes, 2009).

\section{Methodology}

\subsection{Objectives}

The main objective detailed in this work is to evaluate the impact that MAESE has on its participants. This general objective can be specified as follows:

1. To identify the impact that the Master course in Socioemotional Learning has had on socioemotional competence, positive psychology (dispositional optimism, satisfaction with life), coaching, and the capacity for entrepreneurship and innovation of the participants of four consecutive graduating classes.

\subsection{Design}

The methodology used in this study is quasi-experimental and eminently quantitative through an ex post facto study replicated over four years, in the form of consecutive graduating classes, with different samples each year. We complemented the quantitative methodology with the qualitative methodology in the last two modules since we collected complementary information through open-ended questions. This type of research provides us with facts and data and shows us the impact that educational interventions can have on the dependent variables of the study (Pérez Juste, 2004).

In this study we carry out an individualized follow-up of tutorials with the participants, in this way we control the strange variables (1) complementary training in similar topics, 2) drastic changes at a personal level and 3) significant changes at a professional level), variables can influence the dependent variables (1) socioemotional competence, 2) dispositional optimism, 3) satisfaction with life, 4) personal and professional coaching training, 5) entrepreneurship capacity, and 6) innovation capacity), and which are not a consequence of the independent variable (MAESE training program). People who do not meet these requirements and are affected by strange variables have not been included in the final sample of said study. Therefore, we confirm that, except for other strange variables beyond our control, the changes obtained between the pre-test and post-test are attributed to the training received at MAESE. 


\subsection{Sample}

The sample of this study is made up of 84 students taking the MAESE during the school years 2014-2015, 2015-2016, 2016-2017 and 2017-2018. This means that all the participants were part of the quasi-experimental condition, with 17 of them being male (20\%) and 67 of them female $(80 \%)$. The mean overall age was 28.65 years. All participants had higher-education or undergraduate degrees in Psychology, Pedagogy, Teaching, or related professional fields.

The international ethical criteria included in the Declaration of Helsinki have been followed. The personal data of the experimental subjects participating in this study is completely confidential, in accordance with the Organic Law 3/2018, of December 5, on the Protection of Personal Data. The anonymity of the responses and scores of all participants was guaranteed and respected.

\subsection{Procedure}

In this paper, the intervention was considered the training received by the MAESE students, which has been organized into the four modules mentioned: 1) socioemotional intelligence, 2) positive psychology, 3) communicative and team coaching, and 4) entrepreneurship and innovation.

The learning acquired in each of these modules by the students emerged not only from the theoretical training offered by the teachers but also from the practical sessions, the seminars, and the active and self-directed work of the students that is promoted in this Master course. Specifically, the theoretical-practical sessions and the seminars in the different modules have been organized as follows (Table 1):

Table 1. Timeline of the Intervention during the Four Years of Study in MAESE

\begin{tabular}{ll}
\hline \multicolumn{1}{c}{ October } & \multicolumn{1}{c}{ Pretest Evaluation } \\
\hline October - November & Socioemotional Learning module \\
December - January & Positive Psychology module \\
February - March & Communicative and Team Coaching module \\
April & Entrepreneurship and Innovation module \\
May - May & External internships \\
June & Posttest evaluation \\
\hline
\end{tabular}

\subsection{Instruments}

The socioemotional intelligence demonstrated by the participants of the study, as well as how they viewed their own dispositional optimism, satisfaction with life, and ability to undertake projects and innovate and the contribution of coaching to their personal and professional lives, are evaluated with different tests, all of them validated and with psychometric guarantees of reliability and validity.

Specifically, to evaluate the dependent variables under study, the following five evaluation 
instruments have been used:

1. Mayer-Salovey-Caruso Emotional Intelligence Test (MSCEIT) (Mayer, Salovey, \& Caruso, 2002). This instrument measures the socioemotional ability of subjects based on the four-branch model of emotional intelligence (Mayer \& Salovey, 2007). Thus, it offers standardized scores for the competences of perceiving emotions, understood as the ability to consciously recognize our emotions and identify what we feel, in addition to being able to give it a verbal label; facilitating thought, or the ability to generate feelings that facilitate thinking; understanding emotions, or the ability to combine what we feel and think with an understanding of the complexity of emotional changes; and managing emotions, or the ability to direct and manage feelings, both positive and negative, effectively. It is a test of ability, so that the subjects' responses are not based on the perceptions they have about their own competences but on demonstrating that they possess them. This aspect gives much reliability to the test and its outcomes.

2. Life Orientation Test (Optimism) (Scheier, Carver, \& Bridges, 1994). In this work, the revised Life Orientation Test - LOT-R (Scheier et al., 1994) was used as validated for Spanish by Otero, Luengo, Romero, Gómez, and Castro (1998). The updated LOT-R consists of six items (plus four filler items to make the content less obvious) on a 5-point Likert scale (Chico, 2002). Of these, three are written in a positive direction (optimism) and three in a negative direction (pessimism), the latter of which are reversed to obtain a total score tending towards the optimism pole.

3. Satisfaction With Life Scale (SWLS) (Diener, Emmons, Larsen, \& Griffin, 1985). This scale consists of five items that evaluate satisfaction with life through one's global cognitive judgment of it. For the present work, the Spanish translation of Atienza, Pons, Balaguer, and García-Merita (2000) was used, which presents the statements as follows: (a) "In most ways, my life is close to my ideal"; (b) "So far, I have gotten the important things I want in life"; (c) "I am satisfied with my life"; (d) "If I could live my life over, I would change almost nothing"; and (e) "The conditions of my life are excellent". In this version, a reduction was made in the response options of the instrument (the original version had 7), so the values range between 1 and 5, where 1 is "strongly disagree" and 5 is "strongly agree". The total score ranges from 5 (extremely dissatisfied) to 25 (extremely satisfied). Satisfaction with life refers to a process of cognitive judgment that is intimately linked to the skills developed in positive psychology (positive reinterpretation of past events, dispositional optimism, openness, etc.)

4. Coaching and life. An open-ended questionnaire consisting of two exercises: 1) what a person wants and has in their life, what they do not want and do not have, and whether they intend to maintain or change it (before and after); and 2) what personal and professional aspects does the person think can be changed with coaching (before) and which ones have truly produced a change (after). To develop these open-ended tests, their relevance was validated by two people affiliated with the world of coaching, considering the aspects addressed in this part of the study. After some adjustments, the four consecutive graduating classes were given this questionnaire ex post facto. 
5. Entrepreneurship and Innovation Scale, adapted from the Passion Toward Work Scale (PTWS) of Vallerand and Houlfort (2003) and from the test to evaluate the entrepreneurial capacity of the professional guidance guidelines of the Government of Aragon (2008). This scale can be found in Annex 1. It starts with 12 questions that have three response options, (a), (b), and (c). The entrepreneurship and innovation scale has been complemented with open-ended questions to know what meaning students attribute to the concepts of entrepreneurship and innovation.

All these tests were answered by the participants of this study in a preintervention phase (pretest) and after the Master classes (posttest) were completed, over four consecutive years, so that the results obtained in a given student's questionnaires reflect any improvement, which was presumably due largely to the structured intervention in the MAESE.

\section{Results}

In this section, we present the results found and distributed in the four evaluated study blocks: 1) socioemotional intelligence, 2) positive psychology, 3) team coaching, and 4) entrepreneurship and innovation.

The data obtained in the first two modules were submitted to quantitative analyses, while the data collected from the third and fourth modules were analyzed through units of analysis, predefined competences (innovation, entrepreneurship, coaching), and competences that emerged inductively (self-esteem, effectiveness, decision-making, etc.).

\subsection{Socioemotional Intelligence}

After administering the Mayer-Salovey-Caruso emotional intelligence pretest and posttest (Mayer et al., 2002) to the participants, no statistically significant differences in global socioemotional intelligence were observed (Table 2). This result can be explained by two parameters already highlighted by Salovey, Mayer, Caruso, and Lopes (2002).

Table 2. Evolution of the Level of Socioemotional Intelligence

\begin{tabular}{|c|c|c|c|c|c|}
\hline \multicolumn{2}{|c|}{ Socioemotional intelligence (MSCEIT) } & \multirow{2}{*}{$\begin{array}{c}\text { Mean } \\
102,33\end{array}$} & \multirow{2}{*}{$\frac{\mathrm{SD}}{11,944}$} & \multirow{2}{*}{$\frac{t}{-1,443}$} & \multirow{2}{*}{$\begin{array}{c}\mathrm{P} \\
, 153\end{array}$} \\
\hline Perceiving emotions & Pre-test & & & & \\
\hline & Post-test & 100,18 & 13,503 & & \\
\hline \multirow[t]{2}{*}{ Facilitating emotions } & Pre-test & 101,06 & 13,564 & 1,479 &, 143 \\
\hline & Post-test & 103,68 & 13,398 & & \\
\hline \multirow[t]{2}{*}{ Understanding emotions } & Pre-test & 104,70 & 12,383 & ,448 & 655 \\
\hline & Post-test & 105,40 & 12,981 & & \\
\hline \multirow[t]{2}{*}{ Managing emotions } & Pre-test & 104,98 & 14,112 & 1,554 &, 124 \\
\hline & Post-test & 107,45 & 13,565 & & \\
\hline \multirow[t]{3}{*}{ Total CI } & Pre-test & 110,72 & 14,587 &, 057 & ,955 \\
\hline & Post-test & 110,82 & 13,977 & & \\
\hline & \multicolumn{5}{|c|}{$\mathrm{N}=81$} \\
\hline
\end{tabular}


1) The scale is based on high levels of emotional perception, as well as facilitating thought, understanding emotions, and managing emotions. Following Brackett, Mayer, and Warner (2004), this may limit room for improvement or significant progress. This situation thus predisposed the results to an insignificant advance of the parameters evaluated in the MSCEIT (Extremera \& Fernández-Berrocal, 2002). Consequently, even though minimal progress was made, the results imply a high level of development. On the other hand, the people who usually enroll in these courses already have high expectations given the importance that these parameters have on the exercise of their profession and on their professional development, which, as indicated by Parker, Hogan, Majeski, and Bond (2017), is something that facilitates training and learning.

2) The length of time was not long enough to observe a significant difference, since each of the interventions was carried out over the course of an academic year, which operationally ends up being seven months of intervention. As stated by Mayer et al. (2002), at least 12 months is necessary to observe significant improvements.

\subsection{Positive Psychology}

After applying the Spanish version of the revised Life Orientation Test - LOT-R (Scheier et al., 1994), the reported Cronbach's alpha was 0.78 , and the correlation with the original LOT was 0.95 (Otero et al., 1998). Statistically significant differences were observed in the variables of positive psychology, perceived life satisfaction, and dispositional optimism (Table 3). These changes were significant, even starting from high levels, if we compare them with previous findings by Arrindell, Meeuwesen, and Huyse (1991) and Pavot and Diener (1993). There was a greater increase in satisfaction with life than in optimism, the latter parameter being the one that according to Ryff (1989) and Ryan and Deci (2001) lays the foundation for life satisfaction.

Table 3. Levels of Satisfaction with Life and Optimism

\begin{tabular}{llcccc}
\hline Positive Psychology & & Mean & SD & t & P \\
\hline Satisfaction with & Pre-test & 24,51 & 5,180 & 5,368 &, 000 \\
Life & Post-test & 27,13 & 4,390 & & \\
Optimism & Pre-test & 22,54 & 3,612 & 5,368 &, 000 \\
& Post-test & 24,57 & 3,909 & & \\
$\mathrm{~N}=84$ & & & & & \\
\hline
\end{tabular}

According to the results found in this study, optimistic people adapted better to life transitions, as shown by other related studies (Arrindell, Heesink, \& Feij, 1999; Glaesmer, Grande, Braehler, \& Roth, 2011; Vázquez, Duque, \& Hervás, 2013).

We found, in line with other studies, such as Remor, Amorós, and Carrobles (2006), that dispositional optimism had a positive effect on psychological and physical well-being. There were significant differences between the levels of initial satisfaction with life (pretest) and final satisfaction with life (posttest) $(t=5.368 ; \mathrm{p}=0.00)$ (Table 3$)$. 


\subsection{Coaching}

The analysis of the data showed that coaching improved well-being, self-knowledge, self-regulation, self-assurance, capacity for reflection, effectiveness, and social, communicative, and teamwork skills. These findings were consistent over the years, although they were not the only benefits manifested in the students (Table 4).

Table 4. Personal and Professional Development from Coaching in the Four Graduating Classes

\begin{tabular}{ll}
\hline Year & How coaching contributes at a personal and professional level \\
\hline 2017 & $\begin{array}{c}\text { Self-esteem, effectiveness, understanding, self-knowledge, decision-making, ability to } \\
\text { reflect, helping others, self-control, communication, starting a business }\end{array}$ \\
2016 & $\begin{array}{c}\text { Ability to reflect, openness, decision making, self-knowledge, self-control, } \\
\text { communication and teamwork, and effectiveness. }\end{array}$ \\
2015 & Self-knowledge, self-control, effectiveness and understanding, capacity for reflection, \\
communication and teamwork \\
2014 Work, Communication, expansion of groups and relationships, cooperation, flexibility, \\
decision-making, self-knowledge, well-being, effectiveness, and self-esteem
\end{tabular}

To gain a deeper understanding of the data obtained so far, we asked the participants to reflect on what aspects of life they have and do not have and want and do not want. While the initial reflections (pretest) reflected ideas focused on the material and external, in the posttest they emphasized ideas linked to self-knowledge and human relationships, based on their experiences with them (Figure 1).

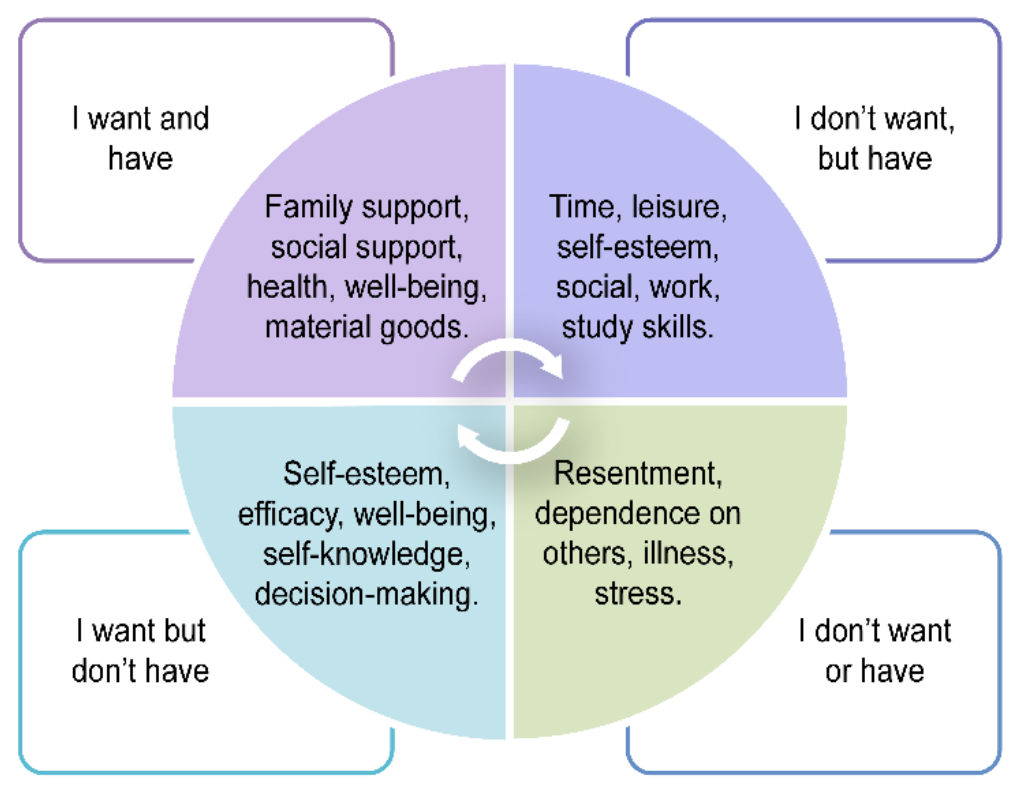

Figure 1. Analysis of Aspects that are or are not Wanted or Had.

Source: Own Elaboration 


\subsection{Entrepreneurship and Innovation}

The analysis of the pretest data reveals that the participants of the four graduating classes participating in the research started from a simplistic definition of innovation and entrepreneurship in which they barely distinguished between the two terms. We analyze below their initial understanding of the terms and their evolution:

Concept of innovation: The initial concept of innovation revolved around bringing something new to society or to a context (micro-macro). After MAESE, the concept of innovation was more nuanced, in which the person was key and was above the methodology, the project, or the idea. The person became the nucleus.

Concept of entrepreneurship: It was at first based on an understanding of the mostly entrepreneurial concept in which the entrepreneur starts a business, takes risks, and invests in it. After MAESE, the concept of entrepreneurship expanded. It started from a possible business vision, although an entrepreneur was defined as a person who maintained a proactive attitude both in the business environment and in the personal and professional in general (educational, social, etc.).

Once the posttest data were analyzed, both terms (innovation and entrepreneurship) acquired more personal nuances, bringing us closer to the vision of innovation from previous studies (Lickona, 2012; Mustari, 2014), in which passion, the search for creative change, motivation, illusion, and enthusiasm are at the forefront. On the other hand, we understand the term "entrepreneurship" together with that defined by Lee, Chung, and Bernhard (2013), which implies bringing ideas to reality, organizing work, committing, being brave, and taking bold risks.

A total of $62 \%$ of the students participating in the research during the four years were considered innovative, an initial level higher than found in previous studies (Lee, Chung \& Bernhard, 2013). Participants understood this type of innovation as contextual innovation applied to their work environment. Once the Master course was complete, the level of innovation of the students increased to $78 \%$, and they attributed a more personal, broad, and holistic view of the concept of innovation. This evolution is linked to competences such as creativity, change management, approaching the unknown, and emotional risk management.

On the other hand, only half of the students who considered themselves innovative perceived themselves as entrepreneurs. The initial concept of entrepreneurship was linked to the creation of a company, and only $31 \%$ considered themselves capable of doing so. Throughout the Master course, the perspective broadened, and $81 \%$ of students defined themselves as entrepreneurs. They understood this concept as a key attitude, not only as the creation of a professional project. Based on the studies of Agih (2017) and Caballero-García, Jiménez-Martínez, and Guillén-Tortajada (2019), some of the parameters that positively influenced the development of entrepreneurship were greater confidence in themselves and other family and social realities that expanded their knowledge, as well as the proposal of clear objectives with openness and consistent effort (Figure 2). 


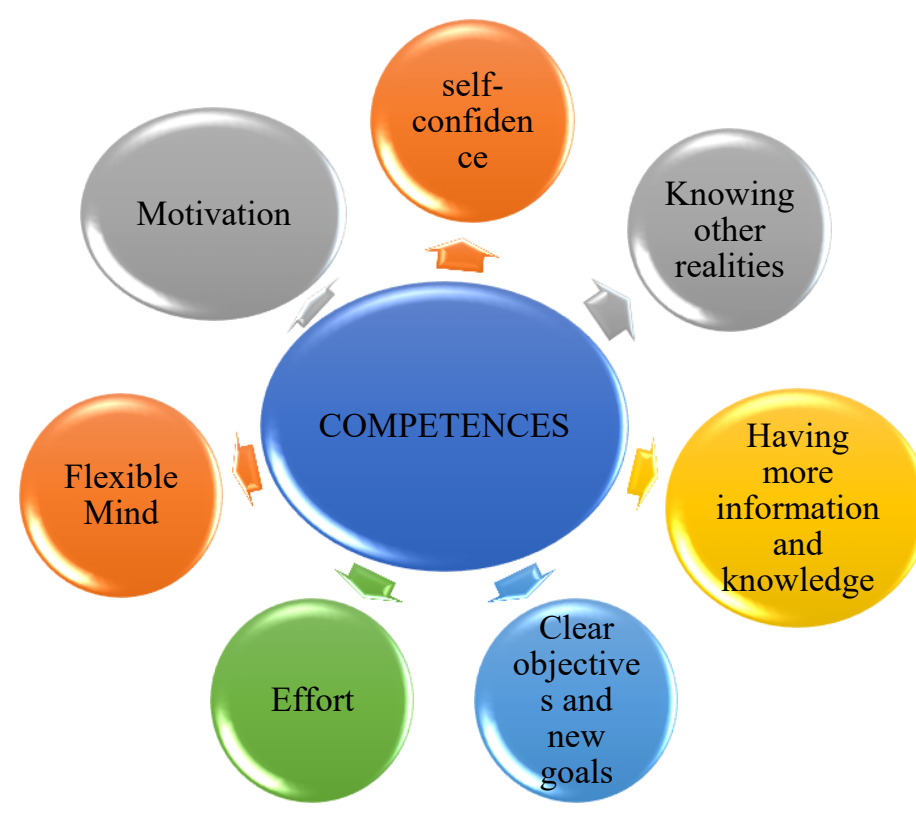

Figure 2. Competences Developed in MAESE that Have Facilitated Participants' Innovation and Entrepreneurship

In our study, participants were considered more innovative than entrepreneurial, although the progression in the level of entrepreneurship was greater. Based on the research carried out by the Spanish Ministry of Education (2007), we have to reinforce the levels of entrepreneurship in the educational field, this being a competence of the citizen of the 21 st century, which reinforces the importance of promoting a set of common values in Western societies (Devriésère, 2020).

\section{Conclusions}

In the vast majority of jobs, people must have not only specific knowledge and technical skills but also a certain level of socioemotional skills that ensure that the worker can work in a team, can stay motivated in the face of difficulties, can resolve interpersonal conflicts, or can tolerate high levels of stress (Repetto \& Pérez-González, 2007). Now more than ever, society is immersed in uncertainty and requires socioemotional skills to adapt to the continuous changes caused by the COVID-19 pandemic and its collateral damage at the personal and professional levels. In this research, we start from the hypothesis that the development of socioemotional skills can be learned and evaluated (Heikkilä, Lonka, Nieminen, \& Niemivirta, 2012), and we distill this learning and evaluation into four factors of interest: 1) socioemotional intelligence (perception, facilitation, understanding, and management), 2) positive psychology (dispositional optimism and satisfaction with life), 3) communicative and team coaching, and 4) entrepreneurship and innovation.

The subjects of this research, four consecutive graduating classes of MAESE (2014-2017), 
largely improved their emotional competences in the four blocks of content analyzed. They showed high levels of competence in perceiving emotions, understood as the ability to consciously recognize their emotions; emotional facilitation of thought, or the ability to generate feelings that facilitate thinking; understanding emotions, or the ability to integrate what we feel into our thinking; and managing emotions, or the ability to direct and manage emotions, both positive and negative, effectively.

Moreover, progression in the levels of optimism, coaching, entrepreneurship, and innovation has been significant and applicable to both the personal and professional fields. The predisposition of the participants has been positive and ambitious, aspects that favor proactivity, curiosity, and motivation to learn. We can conclude by saying that the participants, in addition to acquiring knowledge, have improved their level of satisfaction with life, their optimism, their level of self-knowledge, their self-regulation, their self-assurance, their reflective capacity, their effectiveness, their social and communicative skills, their ability to work in teams, their willingness to undertake risky projects, and their innovativeness. In short, the MAESE has had a positive impact on the level of well-being of the participants in the study.

More and more, different types of national and international training in which socioemotional learning is applied to personal and/or professional development has gained visibility. However, not all of it is worthwhile. We agree that evaluating the training and its impact on participants is important (Petrides \& Furnham, 2003). It is not enough that training be high-quality; we strive for this training to have a positive impact, both personally and professionally, on the students who participate.

Socioemotional skills are increasingly demanded in the 21 st century labor market, at the business, social, and political levels (Rodríguez, Cano, \& Cortes, 2018), as they largely determine success in life and one's state of well-being or level of happiness (Marulanda, Correa, \& Mejía, 2009; Rosero \& Molina, 2008). Assessing the impact of this kind of training allows us to improve it and respond to the needs demanded by the system (De Pablo Valenciano \& Toril, 2009). Part of our responsibility is to verify the scientific notions that support the theories and knowledge that we transmit and/or receive in all the topics taught, and fundamentally in those that have a direct relationship with socioemotional competences.

Applying these skills is not just a matter of interest; it requires effort, time, discipline, and consistency (Parker et al., 2017). To learn, we must be willing to make mistakes, since investing in emotional well-being is counting on oneself and others (Bar-On, 2006; Mayer \& Salovey, 2007). All the countries of the world in general, and the European Higher Education Area in particular, seek to address the emerging globalizing phenomena through adequate management of emotions, since it is effective and efficient to work from that approach. In short, success is that which, from the particularities of each of the improvements, will help shape a more inclusive, sustainable, and emotional society (Devriésère, 2020). 


\section{References}

Agih, A. A. (2017). Integrating elements of the affective domain in teaching, assessment and grading of students' performance for effective learning. Journal of Emerging Trends in Educational Research and Policy Studies, 8(4), 232-236.

Arrindell, W. A., Heesink, J., \& Feij, J. A. (1999). The satisfaction with life scale (SWLS): Appraisal with 1700 healthy young adults in the Netherlands. Personality and Individual Differences, 26(5), 815-826. http://dx.doi.org/10.1016/s0191-8869(98)00180-9

Arrindell, W. A., Meeuwesen, L., \& Huyse, F. J. (1991). The satisfaction with life scale (SWLS): Psychometric properties in a non-psychiatric medical outpatients sample. Personality and Individual Differences, 12(2), 117-123. http://dx.doi.org/10.1016/0191-8869(91)90094-r

Bar-On, R. (2006). The bar-on model of emotional-social intelligence (ESI). Psicothema, 18, 13-25. http://dx.doi.org/10.5772/32468

Bozer, G., \& Jones, R. J. (2018). Understanding the factors that determine workplace coaching effectiveness: A systematic literature review. European Journal of Work and Organizational Psychology, 27(3), 342-361. http://dx.doi.org/10.1080/1359432x.2018.1446946

Brackett, M. A., Mayer, J. D., \& Warner, R. M. (2004). Emotional intelligence and its relation to everyday behaviour. Personality and Individual Differences, 36(6), 1387-1402. http://dx.doi.org/10.1016/s0191-8869(03)00236-8

Bueno, E. (2012). Conocimiento e innovación. Hacia un modelo económico evolutivo-sostenible. In J. Micheli, E. Medellín, J. Jasso, \& A. Hidalgo (Eds.), Innovación y Crisis Trayectorias y respuestas de empresas y sectores (pp. 31-64). México: Universidad Autónoma Metropolitana.

Caballero-García, P. Á., Jiménez-Martínez, M. P., \& Guillén-Tortajada, E. (2019). Aprender a emprender bajo el binomio familia-escuela. Revista Electrónica Interuniversitaria de Formación del Profesorado, 22(3), 139-154. http://dx.doi.org/10.6018/reifop.389611

Cabello, R., Ruiz-Aranda, D., \& Fernández-Berrocal, P. (2009). Docentes emocionalmente inteligentes. Revista Electrónica Interuniversitaria de Formación del Profesorado, 13(1), 41-49.

Cortés, A. (2019). Importamos aportamos. Transformación educativa y social desde el coaching de equipos. Madrid: Síntesis.

Cortés, A., \& Vázquez, S. (2018). Coaching y liderazgo educativo. In A. Cortés, A. Rodríguez, \& S. Val (Eds.), Estrategias transformadoras para la educación Una visión para el siglo XXI (pp. 207-222). Madrid: Piramide.

De Pablo Valenciano, J., \& Toril, J. U. (2009). Emprendimiento de la economía social y desarrollo local: La promoción de incubadoras de empresas de economía social en 
Andalucía. CIRIEC- España, Revista de Economía Pública, Social y Cooperativa, (64), 5-33. http://dx.doi.org/10.7203/ciriec-e.88.6679

Devriésère, V. (2020). The controversy. Revista Electrónica Interuniversitaria de Formación del Profesorado, 23(1), 49-58. http://dx.doi.org/10.6018/reifop.408751

Díaz, O., Cortés, A., \& Serra, A. (2019). ¿Hacia un modelo integral de coaching educativo?: Inferencia hacia competencias ejecutivas y liderazgo. Revista Iberoamericana de Psicología, 12(3), 101-112. http://dx.doi.org/10.33881/2027-1786.rip.1231

Ekman, P. E., \& Davidson, R. J. (1994). The nature of emotion: Fundamental questions. New York: Oxford University Press.

Extremera, N., \& Fernández-Berrocal, P. (2002). Relation of perceived emotional intelligence and health-related quality of life of middle-aged women. Psychological Reports, 91(1), 47-59. http://dx.doi.org/10.2466/pr0.2002.91.1.47

Glaesmer, H., Grande, G., Braehler, E., \& Roth, M. (2011). The German version of the satisfaction with life scale (SWLS). European Journal of Psychological Assessment, 27(2), 127-132. http://dx.doi.org/10.1027/1015-5759/a000058

Heikkilä, A., Lonka, K., Nieminen, J., \& Niemivirta, M. (2012). Relations between teacher students' approaches to learning, cognitive and attributional strategies, well-being, and study $\quad$ success. Higher Education, 64(4), 455-471. http://dx.doi.org/10.1007/s10734-012-9504-9

Herzberg, P. Y., Glaesmer, H., \& Hoyer, J. (2006). Separating optimism and pessimism: A robust psychometric analysis of the revised life orientation test (LOT-R). Psychological Assessment, 18(4), 433-438. http://dx.doi.org/10.1037/1040-3590.18.4.433

Lee, C. K., Chung, N., \& Bernhard, B. J. (2013). Examining the structural relationships among gambling motivation, passion, and consequences of internet sports betting. $\begin{array}{llll}\text { Journal of } \quad \text { Gambling } & \text { Studies, } & 30(4), & \text { 845-858. }\end{array}$ http://dx.doi.org/10.1007/s10899-013-9400-y

Lickona, T. (2012). Education for character building. Jakarta: Bumi Aksara.

Marulanda, J. A., Correa, G., \& Mejía, L. F. (2009). Emprendimiento: Visiones desde las teorias del comportamiento humano. Revista EAN (66), 154-168. http://dx.doi.org/10.21158/01208160.n66.2009.479

Mayer, J. D., \& Salovey, P. (2007). ¿Qué es inteligencia emocional? In J. M. Mestre \& P. Fernández-Berrocal (Eds.), Manual de inteligencia emocional (pp. 25-45). Madrid: Pirámide.

Mayer, J. D., Salovey, P., \& Caruso, D. (2002). Mayer-salovey-caruso emotional intelligence test (MSCEIT). Versión 2.0. Toronto: Multi-Health Systems.

Mustari, M. (2014). Character value: Reflection for education. Jakarta: Rajagrafindo Persada. 
Otero, J. M., Luengo, A., Romero, E., Gómez, J. A., \& Castro, C. (1998). Psicología de la personalidad: Ma- nual de prácticas. Barcelona: Ariel Practicum.

Parker, J. D. A., Hogan, M. J., Majeski, S. A., \& Bond, B. (2017). Assessing emotional intelligence: reliability and validity of the short form for the emotional quotient inventory (EQ-i:Short), 67-84. Retrieved from https://n9.cl/1cmn4

Pavot, W., \& Diener, E. (1993). Review of the satisfaction with life scale. Psychological Assessment, 5(2), 164-172. http://dx.doi.org/10.1037/1040-3590.5.2.164

Pérez Juste, R. (2004). Evaluación de programas en educación. Madrid: La Muralla.

Petrides, K. V., \& Furnham, A. (2003). Trait emotional intelligence: Behavioural validation in two studies of emotion recognition and reactivity to mood induction. European Journal of Personality, 17(1), 39-57. http://dx.doi.org/10.1002/per.466

Remor, E., Amorós, M., \& Carrobles, J. A. (2006). El optimismo y la experiencia de ira en relación con el malestar físico. Anales de Psicología, 22, 37-44.

Repetto, E., \& Pérez-González, J. C. (2007). Formación en competencias socioemocionales a través de las prácticas en empresas. Revista Europea de Formación Profesional, 40(1), 92-112.

Reyes, P. (2009). El rol de la psicología en la innovación. Retrieved from http://blog.pucp.edu.pe/media/avatar/530.pdf (August 5, 2012)

Rodríguez-Ledo, C., Orejudo Hernández, S., Celma Pastor, L., \& Cardoso Moreno, M. J. (2018). Mejora de las competencias socioemocionales en el aula, con jóvenes de educación secundaria, mediante el programa SEA. Electronic Journal of Research in Education Psychology, 16(46), 681-701. http://dx.doi.org/10.25115/ejrep.v16i46.2241

Rodríguez-Ledo, C., Orejudo, S., Cardoso, M. J., Balaguer, Á., \& Zarza-Alzugaray, J. (2018). Emotional intelligence and mindfulness: Relation and enhancement in the classroom $\begin{array}{llll}\text { with adolescents. Frontiers in Psychology, 9, } 2162 . & \text {. }\end{array}$ http://dx.doi.org/10.3389/fpsyg.2018.02162

Rodríguez, A., Cano, J., \& Cortes, A. (2018). Competencias y emprendimiento. In A. Cortés, A. Rodríguez, \& S. Val (Eds.), Estrategias transformadoras para la educación (pp. 247-264). Zaragoza: Pirámide.

Rosero, O., \& Molina, S. (2008). Sobre la investigación en emprendimiento. Informes Psicológicos, (10), 29-39. http://dx.doi.org/10.2307/j.ctv8bt31j.1

Ryan, R. M., \& Deci, E. L. (2001). On happiness and human potentials: A review of research on hedonic and eudaimonic well-being. Annual Review of Psychology, 52(1), 141-166. http://dx.doi.org/10.1146/annurev.psych.52.1.141

Ryff, C. D. (1989). Happiness is everything, or is it? Explorations on the meaning of psychological well-being. Journal of Personality and Social Psychology, 57(6), 1069-1081. http://dx.doi.org/10.1037/0022-3514.57.6.1069 


\section{Macrothink}

Salovey, P., Mayer, J. D., Caruso, D., \& Lopes, P. N. (2002). Measuring emotional intelligence as a set of abilities with the MSCEIT. In S. J. Lopez \& C. R. Zinder (Eds.), Handbook of positive psychology assessment (pp. 251-265). Washington, DC: American Psychological Association.

Scheier, M. F., Carver, C. S., \& Bridges, M. W. (1994). Distinguishing optimism from neuroticism (and trait anxiety, self-mastery, and self-esteem): A reevaluation of the life orientation test. Journal of Personality and Social Psychology, 67(6), 1063-1078. http://dx.doi.org/10.1037/0022-3514.67.6.1063

Spanish Ministry of Education. (2007). School leadership in Spain (Directorate for Education). OECD Country Background Report, Bruselas.

Theeboom, T., Beersma, B., \& van Vianen, A. E. M. (2013). Does coaching work? A meta-analysis on the effects of coaching on individual level outcomes in an organizational context. The Journal of Positive Psychology, 9(1), 1-18. http://dx.doi.org/10.1080/17439760.2013.837499

Vallerand, R. J., \& Houlfort, N. (2003). Passion at work: Toward a new con- ceptualization. In D. Skarlicki, S. Gilliland, \& D. Steiner (Eds.), Social issues in management (pp. 175-204). Greenwich, CT: Information Age.

Vázquez, C., Duque, A., \& Hervás, G. (2013). The satisfaction with life scale (SWLS): Adaptation and normative data in a spanish representative national sample. The Spanish Journal of Psychology, 16, e82. http://dx.doi.org/10.1017/sjp.2013.82

\section{Appendix}

Appendix 1. Test to Evaluate Entrepreneurial and Innovative Capacity

\begin{tabular}{|c|c|c|c|c|}
\hline No. & Questions & Response option "a" & $\begin{array}{l}\text { Response option } \\
\text { "b" }\end{array}$ & Response option "c" \\
\hline 1 & $\begin{array}{l}\text { Do you need to be sure that } \\
\text { something will work before } \\
\text { trying it? }\end{array}$ & $\begin{array}{l}\text { If my instinct says } \\
\text { yes, I can quickly } \\
\text { implement an idea, } \\
\text { even if it is } \\
\text { something radical } \\
\text { that I have not done } \\
\text { before. }\end{array}$ & $\begin{array}{l}\text { I am a person } \\
\text { who plans } \\
\text { everything, and I } \\
\text { need to examine } \\
\text { every detail } \\
\text { before acting. It is } \\
\text { a way of } \\
\text { increasing the } \\
\text { possibility of } \\
\text { success. }\end{array}$ & $\begin{array}{l}\text { I always have new } \\
\text { ideas, but I do not } \\
\text { make them a reality } \\
\text { until I test them well. }\end{array}$ \\
\hline
\end{tabular}


2 How do you feel when you

know you are not the

smartest person in a group?

3 How is your behavior at work/place of study?
4

5

How often do you learn

something new?
Alright. I think that

more intelligent

people will be able

to do things that I

cannot do.

I am generally

happy, but I get

upset if I have to

work late and I

cannot carry out my

personal

responsibilities.

How do you react if you fail?

I am cautious by

nature because

failure affects me. I

have abandoned

projects when I

have seen that they

do not work.

Every day. I spend

time reading or

doing free online

training to learn

about areas that are

new to me.
6

I like an

environment where

I connect with

people inside and

outside my field of

work. Each meeting

is an opportunity to

exchange ideas. In

addition, I use social

networks on the

internet.

7 What is your idea of fun after

a long day?
Go to a new

restaurant
I love what I do, I do not express how and I am always I feel. Whether it is

in good spirits. pleasant or

My colleagues unpleasant, I keep it

say it is a inside.

contagious

attitude.

Failure weakens It is a blow, but it is me, but I keep the most powerful

going, there is way to learn.

nothing more that

can be done.

Every week. I Every month because

learn new things I work a lot.

by watching

television or

surfing the

internet.

The contacts

I use social networks

seem a little

superficial. I

on the internet and

distribute my

prefer real

business cards in

discussions that meetings.

occur naturally.

Watch a favorite

Play some sports with

TV show a friend 
8 How do you describe your personal spending habits?
Even if I have extra

money, I would rather save it than spend it.

9

10 Have you ever worked in sales?

11 In what type of environment do you work best?

12
I am persistent on the phone, by mail, or in person. Constant contact pays off.

Yes. I liked talking to clients, knowing their needs and satisfying them with the

products/projects that best served them.

I am productive in a structured environment, with clear objectives, timelines, and time limits.

I change my schedule on the fly to finish both on time.
I cover my fixed I live and spend in the expenses and moment; I can't take debts, and what I my money to the have left over I grave. spend as I want.

I look for the Once after an initial person once or contact, then I let him twice a week. I do or her come to me. not want to be a bother.

Yes. I did well, No. I do not like the but the concept of pressure of selling a "sales" seems a certain amount in a little limited time. manipulative.

like to do several things at once, and it is better if I can do them on my own terms.

\section{I ask for more} time for the second project.

It is best if a superior challenges me to reach my best potential.

I tell the client that we do not have the necessary time to comply.

\section{Reference responses}

If most of the preferred responses fall under " $a$ ". You have the qualities to take on tasks, the ability to sell yourself and your idea, and put the well-being of the business above your ego. You know how to combine qualities such as organization and planning.

If the preferred responses are mostly " $b$ ". You have the basics for entrepreneurship: passion, risk-taking, and persistence. To perfect these qualities, you have to prepare yourself more, expand your relationships, research on entrepreneurship, create your own project.

If the preferred responses are mostly "c". You should continue improving your qualities. You prefer working in structured environments and prefer a fixed income. Your view of risk is 
conservative, preferring to be certain before making changes.

Source: Entrepreneurship and Innovation Scale, adapted from Passion Toward Work Scale (PTWS) by Vallerand and Houlfort (2003) and the test to evaluate the entrepreneurial capacity of the vocational guidance guides of the Government of Aragon (2008) https://bit.ly/3ecdfZK

\section{Copyright Disclaimer}

Copyright for this article is retained by the author(s), with first publication rights granted to the journal.

This is an open-access article distributed under the terms and conditions of the Creative Commons Attribution license (http://creativecommons.org/licenses/by/3.0/). 